\title{
FAKTOR - FAKTOR YANG TERKAIT DENGAN EKSPOR CRUDE PALM OIL (CPO)
}

\author{
Fauzul Azhimah ${ }^{1)}$, Chaula lutfia saragih ${ }^{2)}$ \\ ${ }^{1) 2)}$ Dosen Universitas Quality \\ Email : fauzulazhimah@ymail.com
}

\begin{abstract}
ABSTRAK
Penelitian ini bertujuan untuk menganalisis keseimbangan jangka panjang dan error term, harga ekspor $\mathrm{CPO}$, harga minyak kedelai dunia, produksi domestik CPO, inflasi, kurs, pajak ekspor yang berlakuterhadap volume ekspor CPO. Metode analisis yang digunakan analisis kointegrasi Engle Granger, Error Correction Model (ECM) dan diselesaikandenganE-Views.Data penelitian adalah data sekunder mingguan dari tahun 2006 - 2015.Data dianalisis dengan metode kointegrasi Engle Granger dan Error Correction Model.Hasil analisis menunjukkan pada kointegrasi jangka panjang terdapat keterkaitan cenderung positif antara harga ekspor CPO, harga minyak kedelai dan produksi domestik CPO terhadap ekspor CPO.Sedangkan variabel inflasi, kurs, dan pajak ekspor menunjukkan keterkaitan yang cenderung negatif terhadap ekspor CPO. Pada estimasi ECM terdapat keterkaitan yang cenderung positif antara harga ekspor CPO, harga minyak kedelai dan produksi domestik CPO terhadap ekspor CPO.Sedangkan variabel inflasi, kurs, dan pajak ekspor menunjukkan kecenderungan negatif terhadap ekspor CPO.
\end{abstract}

\section{Kata kunci : Ekspor CPO, Keterkaitan, Jangka Panjang, ECM.}

\section{ABSTRACT}

This study aims to analyze the balance of long-term and error term, CPO export prices, world soybean oil prices, domestic CPO production, inflation, exchange rate, export tax applicable to the export volume of $C P O$. The analytical method used Engle Granger cointegration analysis,Error Correction Model (ECM) and completed with E-Views. The research data is secondary weeklydata from year 2006 - 2015. The data is analyzed by Engel Granger cointegration and Error Correction Modelmethod. The result of the analysis shows that there is a positive correlation between $C P O$ export price, soybean oil and domestic CPO to export of $C P O$. While the inflation, exchange rate, and export tax variables show a negative correlation to CPO exports. In estimation of error-term, there is a positive correlation to $\mathrm{CPO}$ export price variables, soybean oil price and CPO domestic production. While the variables of inflation, exchange rate and export tax show negative correlation to CPO exports.

Key words : Export of CPO, Related, Long Term, ECM 
PENDAHULUAN

Perdagangan internasional merupakan kegiatan perdagangan yang dilakukan lintas negara dengan menyepakati ketetapan harga komoditi, jumlah, dan waktu transaksi.Kondisi ini dapat dilihat pada perdagangan komoditi olahan kelapa sawit yaitu Crude Palm Oil(CPO) (Saylor.org, 2015).

Perdagangan $\mathrm{CPO}$ bermanfaat sebagai pemasukan keuangan (income) pemerintah atau devisa dimana tahun 2014 devisa dari ekspor CPO mencapai nilai USD19,56 miliar (Lestarini, 2016). Indonesia melakukan ekspor CPO disebabkan adanya produksi perkebunan kelapa sawit dengan produk utama Crude Palm Oil (CPO) dalam jumlah besar yang dapat ditunjukkan dalam grafik berikut

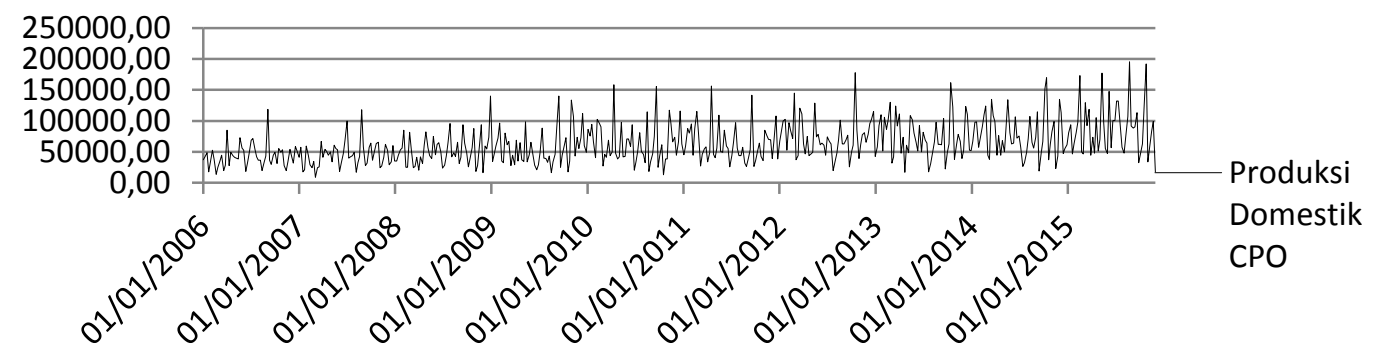

Sumber : BPS 2006 - 2015

\section{Gambar 1. Perkembangan Produksi CPO Indonesia}

Produksi CPO yang pada gambar 1 relatif meningkat pada rentang waktu 2013 hingga 2015.Peningkatan produksi mendorong produsen $\mathrm{CPO}$ cenderung mengekspor CPO untuk mendapatkan keuntungan lebih besar
(Muslih et. al, 2013). Namun yang terjadi adalah perkembangan ekspor CPO Indonesia tidak meningkat yang signifikan dalam rentang waktu tersebut yagn diperlihatkan gambar berikut 


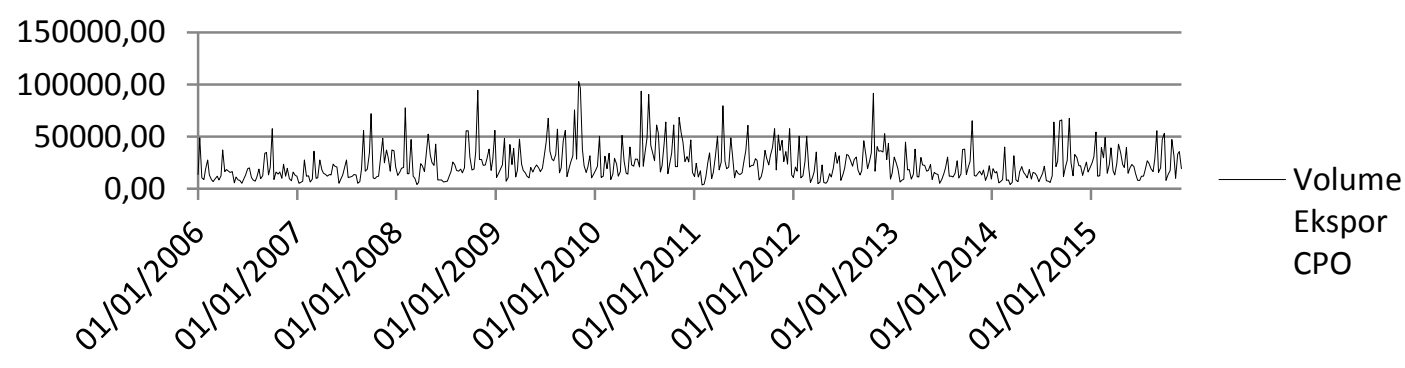

Sumber : BPS 2006 - 2015

\section{Gambar 2. Perkembangan Ekspor CPO}

Perkembangan ekspor CPO yang menggalakkan hilirisasi CPO dengan relatif konstan tidak menunjukkan dukungan berupa bea keluar atau pengaruhantara produksi dan ekspor . pajak ekspor. (Kemenkeu, 2015).

Hal mengindikasikan adanya tekanan Perkembangan pajak ekspor dan dari pemerintah untuk menekan ekspor CPO dapat dilihat dalam jumlah ekspor CPO Indonesia gambar berikut

\section{(PTPN V, 2015). Pemerintah}

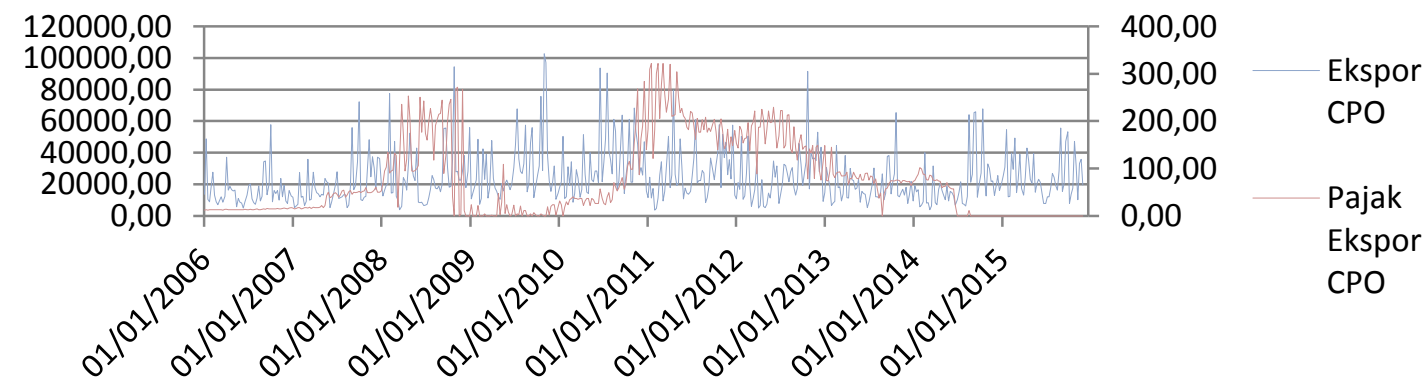

Sumber : BPS 2006 - 2015 dan Kemenkeu 2005 - 2015

\section{Gambar 3. Perkembangan Pajak Ekspor Dan Ekspor CPO}

Perkembangan pajak ekspor dan ekspor CPO tidak menunjukkan keterkaitan yang signifikan.Hal ini diindikasikan karena adanya estimasi eksportir atau produsen CPO memilih keuntungan yang lebih besar dengan mengekspor CPO.Keuntungan yang lebih besar ini diperoleh dari perbedaan nilai kurs.Kurs sering mengalami fluktuasi nilaiyang diakibatkan kebijakan moneter dalam negeri maupun luar negeri (Williamson, 2014). Berikut perkembangan kurs USD terhadap IDR dengan ekspor $\mathrm{CPO}$ 


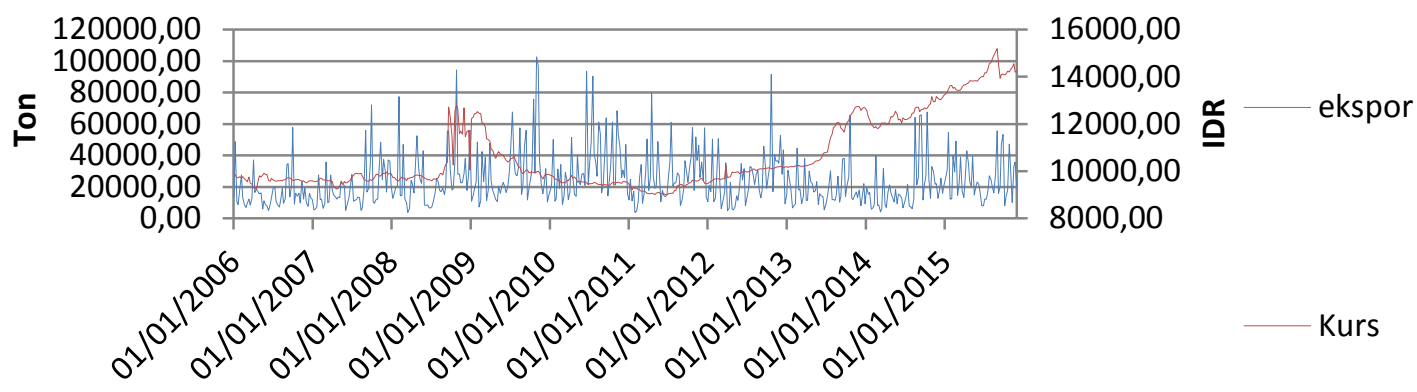

Sumber : BI 2006 - 2015 dan BPS $2006-2015$

\section{Gambar 4. Perbandingan Perkembangan Kurs Dengan Ekspor CPO}

Perkembangan kurs dan ekspor CPO menunjukkan perkembangan ekspor CPO relatif konstan sedangkan kurs berfluktuasi terkait dengan nilai inflasi yang terjadi (Mankiw,
2013).Pelemahan nilai kurs yang terjadi selama kurang lebih empat tahun terakhir diindikasikan adanya deflasi di Indonesia. Hal tersebut dapat dilihat dalam gambar berikut :

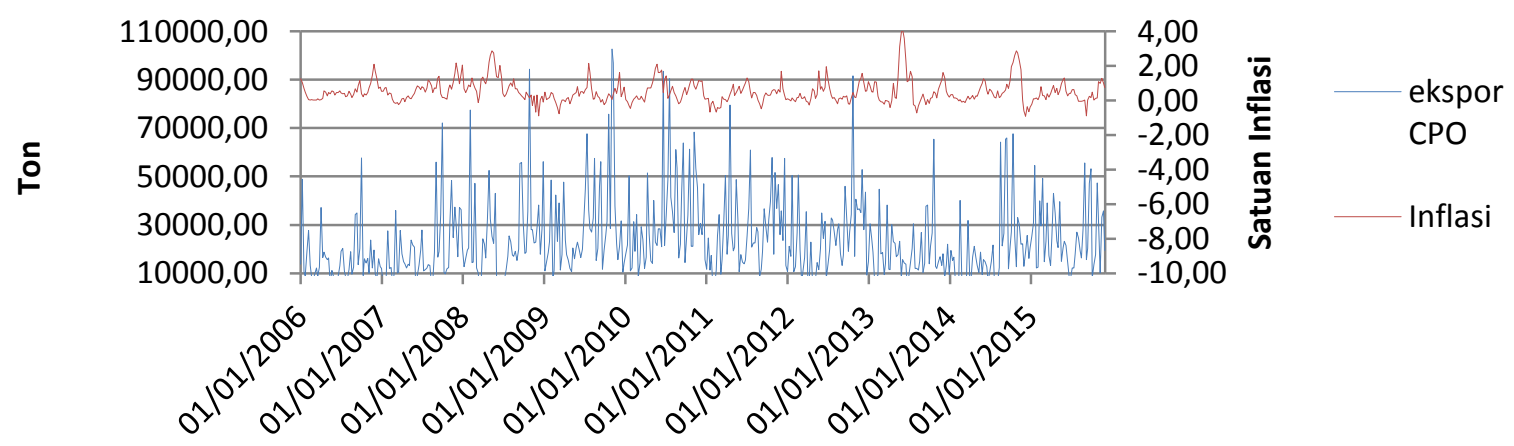

Sumber : BPS $2006-2015$

\section{Gambar 5. Perkembangan Inflasi dan Kaitannya dengan Ekspor CPO}

Gambar 5 menunjukkan adanya deflasi saat peningkatan ekspor CPO dan inflasi saat penurunan ekspor CPO.Bedasarkan kondisi tersebut, diindikasikan ekspor CPO cenderung berkurang pada saat harga ekspor CPO Indonesia cenderung
melemah.Walaupun nilai kurs meningkat, dengan harga ekspor yang semakin murah,mendorong produsen untuk mengurangi ekspor CPOnya. Perkembangan harga ekspor CPOdan volume ekspor dapat dilihat pada gambar berikut 


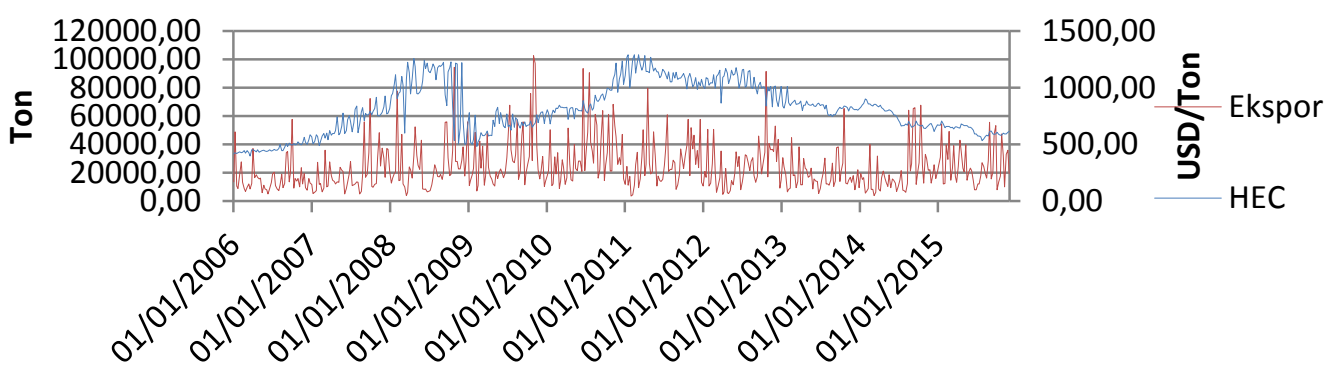

Sumber : BPS 2006 - 2015 dan Bappepti

\section{Gambar 6. Perkembangan Ekspor CPO Dan Harga Ekspor CPO}

Gambar 6tidak menunjukkan keterkaitan antara harga dan volume ekspor CPO.Harga ekspor CPO dianggap sama untuk semua negara tujuan. Hal ini dilakukan untuk melihat perbandingan harga ekspor
CPO Indonesia dengan harga barang kompetitor $\mathrm{CPO}$ yaitu minyak kedelai. Persaingan antar dua minyak nabati tersebut dapat dilihat dari persaingan harga pada grafik berikut

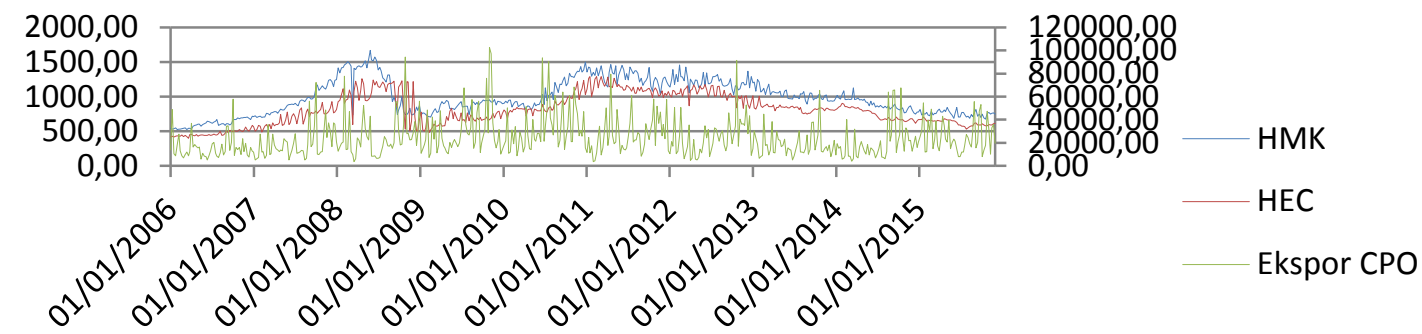

Sumber : USDA 2006 - 2015, Bappepti, dan BPS

\section{Gambar 7. Perkembangan Harga Minyak Kedelai dan Harga Ekspor CPO}

Gambar 7 menunjukkan keunggulan harga ekspor $\mathrm{CPO}$ Indonesia dengan harga internasional minyak kedelai, dimana harga ekspor CPO Indonesia lebih murah daripada harga internasional minyak kedelai.

Permasalahan dari sektor makro dan mikro ekonomi diatas diindikasikan memiliki keterkaitan terhadap ekspor CPO Indonesia.Indikasi diambil dari teoriteori yang terkait dengan ekspor.Jika dilihat dari grafik yang keterkaitan tidak terlihat jelas maka dari itu untuk membuktikan keterkaitan antara insturmen - instrumen 
ekonomi makro dan mikro tersebut terhadap ekspor CPO dilakukan penelitian keterkaitan faktor - faktor yang terkait dengan ekspor Crude Palm Oil Indonesia.

\section{Identifikasi Masalah}

Bagaimana keseimbangan jangka panjang dan jangka pendek harga ekspor CPO, harga minyak kedelai dunia, produksi domestik CPO, inflasi, kurs Rupiah terhadap Dollar Amerika, pajak ekspor yang berlaku terhadap ekspor Crude Palm Oil (CPO) Indonesia.

\section{Tujuan Penelitian}

Menganalisis keseimbangan jangka panjang dan jangka pendek harga ekspor CPO, harga minyak kedelai dunia, produksi domestik CPO, inflasi, kurs Rupiah terhadap Dollar Amerika, pajak ekspor yang berlaku terhadap ekspor Crude Palm Oil (CPO) Indonesia.

\section{LANDASAN TEORI}

\section{Perdagangan Internasional}

Teori perdagangan internasional dibedakan atas dua klasifikasi yaitu teori klasik dan teori modern.Teori klasik perdagangan internasional dikenal ada 3 teori yaitu teori Adam Smith (keunggulan absolut), Teori John Stuart Mill (keunggulan relativedan teori David Ricardo (biaya komparatif).Selanjutnya teori modern dikenal ada 2 teori yaitu teori Heckser Ohlin (faktor proporsi)dan teori parsial atau permintaan dan penawaran (Gerber, 2014).

\section{Teori Nilai Tukar}

Kurs terbagi menjadi dua jenis yaitu kurs nominal dan kurs riil.Nilai kurs riil berpengaruh pada perdagangan karena menimbulkan kecenderungan pembelian barang impor.Jika kurs menurun maka konsumen cenderung membeli barang impor dan sebaliknya.Jika kurs menurun maka harga barangbarang domestik relatif lebih mahal dan sebaliknya.Peralihan konsumen ke barang domestik mengakibatkan nilai ekspor meningkat (Maryana, 2011).

\section{Teori Inflasi}

Inflasi merupakan implikasi dari suatu kondisi di mana lebih banyak uang beredar daripada barang di pasar.Inflasi juga menggambarkan kondisi tejadinya kenaikan hargaharga secara umum.Penyebab terjadinya inflasi dapat diidentifikasi 
dari sumber terjadinya mempunyai pengaruh positif inflasi.Seluruh faktor yang terhadap ekspor CPO ke Uni Eropa mendorong permintaan agregat ke kanan atas maupun penawaran agregat ke kiri adalah faktor yang menyebabkan inflasi.Inflasi yang disebabkan tarikan permintaan agregat disebut demand push inflation dan inflasi yang disebabkan pergeseran kurva penawaran agregat ke kiri disebut inflasi karena dorongan penawaran (cost push inflation) (Supriana, 2011).

\section{Penelitian Terdahulu}

Radifan (2014) dengan judul faktor-faktor yang mempengaruhi ekspor Crude Palm Oil (CPO) Indonesia dalam perdagangan internasional. Hasil penelitian ini mengungkapkan bahwa produksi CPO Indonesia, kurs Rupiah terhadap Dolar AS, dan harga minyak mentah dunia dalam jangka panjang berpengaruh positif dan signifikan terhadap ekspor CPO Indonesia.

Pratiwi (2011) dengan judul analisis determinan ekspor Crude Palm Oil (CPO) Indonesia ke Uni Eropa.Hasil penelitian ini mengungkapkan nilai tukar, produksi $\mathrm{CPO}$, dan produksi minyak goreng 
METODE PENELITIAN

Jenis Dan Sumber Data

Data yang digunakan dalam penelitian ini adalah data mingguandaritahun 2006-2015 sehingga jumlah data dalam penelitian ini adalah 518 data.Data yang digunakan dalam penelitian inidiperolehdariberbagaisumber.Beri kuttabeljenis data dansumbersumbernya :

Tabel 1. Jenis Dan Sumber Data

\begin{tabular}{|c|c|c|c|c|}
\hline Data & $\begin{array}{c}\text { Singkata } \\
\mathrm{n}\end{array}$ & $\begin{array}{l}\text { Frekuensi } \\
\text { Data }\end{array}$ & Satuan & Sumber Data \\
\hline Volume EksporCPO & VEC & Mingguan & Ton & $\begin{array}{l}\text { BadanPusatStatistik } \\
\text { Badan Pengawas }\end{array}$ \\
\hline HargaEksporCPO & HEC & Mingguan & USD/Ton & $\begin{array}{l}\text { Perdagangan Berjangka } \\
\text { Komoditi }\end{array}$ \\
\hline HargaMinyakKedelai & HMK & Mingguan & USD/Ton & $\begin{array}{l}\text { United State Depatment } \\
\text { Agriculture }\end{array}$ \\
\hline ProduksiCPO & PC & Mingguan & Ton & BadanPusatStatistik \\
\hline Inflasi & I & Mingguan & - & BadanPusatStatistik \\
\hline Kurs & $\mathrm{K}$ & Mingguan & Rupiah & Bank Indonesia \\
\hline PajakEkspor & PE & Mingguan & USD/Ton & MenteriKeuangan \\
\hline
\end{tabular}

Sumber : DBC, Dinbun, BPS, BI, USDA

\section{Metode Analisis Data}

Penelitian ini dilakukan untuk melihat keterkaitan jangka panjang danError Correction.Analisis data penelitianini adalah analisis kointegrasi Engle GrangerdanError Correction Model (ECM) diselesaikandenganaplikasi EViews.Langkah-langkah pengujian kointegrasi Engle Grangeradalah sebagai berikut :

\section{Uji Stasioneritas}

Data deret waktumemiliki syarat harus stasioner agar hasil estimasi yang dihasilkan tidak spurious atau palsu. Syarat data stasioner adalah sebagai berikut:
$E\left(X_{t}\right)=$ konstan untuk semua $\mathrm{t}$

$\operatorname{Var}\left(X_{t}\right)=$ konstan untuk semua $\mathrm{t}$

$\operatorname{Cov}\left(X_{t}, X_{t+k}\right)=$ konstan untuk

semua $\mathrm{t}$ dan $\mathrm{k}$ dimana $\mathrm{k} \neq 0$

Pengujian stasioneritas data deret waktu secara statistikal adalah pengujian melalui uji Augmented Dickey Fuller (DF Test). Pengujian stasioneritas dilakukan dengan membandingkan nilai statistik DF dengan nilai probabilitas Mac Kinnon dan nilai kritis $A D F$. $A D F$ test dilakukan pada masing - masing variabel dan dirumuskan dalam bentuk autoregressive. Nilai DF hitung dapat dicari dengan rumusan berikut (Greene, 2002) : 
$\mathrm{DF}_{\mathrm{t}}=\frac{\widehat{y_{t}}}{\widehat{y_{t}} \cdot \sigma}$

Dimana $: \widehat{y_{t}}=$ Variabel dependen estimasi

$$
\sigma=\text { Standar erorr }
$$

$\mathrm{H}_{0}$ diterima $: \mathrm{DF}<$ Nilai Kritis $\mathrm{DF}$ atau Mc Kinnon

$\mathrm{H}_{0}$ ditolak : $\mathrm{DF}>$ Nilai Kritis $\mathrm{DF}$ atau Mc Kinnon

Apabila seluruh data bersifat stasioner pada level, dapat langsung dilakukan pengujian - pungujian selanjutnya. Namun apabila pengujian pada level menunjukkan data tersebut tidak stasioner maka estimasidilakukanlagipadabentukfirst difference.

\section{Uji Kointegrasi}

Pendekatan kointegrasi Engle Granger terdiri dari dua tahap. Tahap pertama dilakukan dengan meregresikan variabel dependen dengan variabel independen, sehingga didapat persamaan regresi seperti berikut :

$$
Y_{t}=b_{0}+b_{1} X_{t}+e_{t}
$$

Variabel dependen dan independen cenderung tidak stasioner pada level, tapi residual dari persamaan regresi harus stasioner pada differensiasi yang sama (stasioner pada diferensiasi

pertama). Untuk menunjukkan hal itu, persamaan ditulis kembali sebagai berikut: $e_{t}=Y_{t}-b_{0}-b_{1} X_{t}$

Persamaan (3) jika diinterpretasikan dalam penelitian ini menjadi persamaan berikut :

$$
\begin{aligned}
& V E C_{t}=\alpha+\beta H E C_{t}+\gamma H M K_{t}+ \\
& \delta P C_{t}+\varepsilon I_{t}+\zeta K_{t}+\eta P E_{t}+u_{t} \ldots
\end{aligned}
$$

Pada penelitian persamaan error term dapat dilihat dalam persamaan berikut :

$$
\begin{aligned}
& e_{t}=V E C_{t}-\alpha+\beta H E C_{t}+ \\
& \gamma H M K_{t}+\delta P C_{t}+\varepsilon I_{t}+\zeta K_{t}+\eta P E_{t}
\end{aligned}
$$

Tahap kedua dilakukan dengan pengujian akarunitterhadap error term dengan hipotesis yang sama dengan hipotesis akar-akar unit ADF. Error term merupakan kombinasi linear, jika hipotesis nol ditolak atau signifikan maka variabel error term stasioner pada level, dan kedua variabel terkointegrasi. Meskipun ..variabel......variabel...yang digunakan tidak stasioner pada level namun dalam jangka panjang variabel - variabel tersebut cenderung menuju pada keseimbangan. Oleh karena itu, 
kombinasilinear dari variabel variabel ini disebut regresi kointegrasi dan parameter parameter yang dihasilkan dari kombinasi tersebut dapat disebut sebagai co-integrated parameters atau koefisien jangka panjang. Pengambilan keputusan metode kointegrasi Granger ini adalah :

$\mathrm{H}_{\mathrm{o}}$ diterima : (ADF stat > Prob Mc Kinnon $)_{\text {variabel }}>(\mathrm{ADF}$ stat $>$ Prob Mc Kinnon) $)_{\text {residual }}$

$\mathrm{H}_{\mathrm{o}}$ diterima : $(\mathrm{ADF}$ stat $>$ Prob $\mathrm{Mc}$

Kinnon $)_{\text {variabel }}<($ ADF stat $>$ Prob Mc

Kinnon) $)_{\text {residual }}$
HASIL DAN PEMBAHASAN

Uji Stasioneritas

Pengujian data time series harus diawali dari asumsi analisis time series yaitu stasioneritas. Jika asumsi ini tidak dipenuhi maka hasil estimasi yang dihasilkan akan palsu dan keputusan maupun kebijakan yang dihasilkan tidak tepat. Berikut hasil pengujian stasioneritas data time series yang dilakukan dalam penelitian ini.

Tabel 2. Pengujian Stasioneritas

\begin{tabular}{|c|c|c|c|c|c|c|}
\hline \multirow[b]{2}{*}{ Variabel } & \multirow[b]{2}{*}{ Tingkat Unit Akar } & \multirow[b]{2}{*}{ Nilai ADF Statistik } & \multicolumn{3}{|c|}{ Nilai Kritis ADF } & \multirow{2}{*}{$\begin{array}{c}\text { Nilai } \\
\text { Kritis } \\
\text { Mac } \\
\text { Kinnon }\end{array}$} \\
\hline & & & $1 \%$ & $5 \%$ & $10 \%$ & \\
\hline $\begin{array}{l}\text { Harga } \\
\text { Ekspor }\end{array}$ & Level & 1,70 & 3,44 & 2,86 & 2,56 & 0,42 \\
\hline $\begin{array}{l}\text { CPO } \\
\text { (HEC) }\end{array}$ & $1^{\text {st }}$ difference & 29,98 & 3,44 & 2,86 & 2,56 & 0,00 \\
\hline $\begin{array}{l}\text { Harga } \\
\text { Minyak }\end{array}$ & Level & 2,03 & 3,44 & 2,86 & 2,56 & 0,27 \\
\hline $\begin{array}{l}\text { Kedelai } \\
\text { (HMK) }\end{array}$ & $1^{\text {st }}$ difference & 20,20 & 3,44 & 2,86 & 2,56 & 0,00 \\
\hline Inflasi (I) & $\begin{array}{l}\text { Level } \\
1^{\text {st }} \text { difference }\end{array}$ & $\begin{array}{l}7,98 \\
17,9\end{array}$ & $\begin{array}{l}3,44 \\
3,44\end{array}$ & $\begin{array}{l}2,86 \\
2,86\end{array}$ & $\begin{array}{l}2,56 \\
2,56\end{array}$ & $\begin{array}{l}0,00 \\
0,00\end{array}$ \\
\hline Kurs (K) & $\begin{array}{l}\text { Level } \\
1^{\text {st }} \text { difference }\end{array}$ & $\begin{array}{r}\mathbf{0 , 3 1} \\
18,46\end{array}$ & $\begin{array}{l}3,44 \\
3,44\end{array}$ & $\begin{array}{l}2,86 \\
2,86\end{array}$ & $\begin{array}{l}2,56 \\
2,56\end{array}$ & $\begin{array}{l}0,97 \\
0,00\end{array}$ \\
\hline Pajak & Level & 1,56 & 3,44 & 2,86 & 2,56 & 0,49 \\
\hline $\begin{array}{l}\text { Ekspor } \\
\text { (PE) }\end{array}$ & $1^{\text {st }}$ difference & 30,38 & 3,44 & 2,86 & 2,56 & 0,00 \\
\hline Produksi & Level & 2,78 & 3,44 & 2,86 & 2,56 & 0,06 \\
\hline $\mathrm{CPO}(\mathrm{PC})$ & $1^{\text {st }}$ difference & 19,34 & 3,44 & 2,86 & 2,56 & 0,00 \\
\hline $\begin{array}{l}\text { Volume } \\
\text { Ekspor }\end{array}$ & Level & 5,94 & 3,44 & 2,86 & 2,56 & 0,00 \\
\hline $\begin{array}{l}\text { CPO } \\
\text { (VEC) }\end{array}$ & $1^{\text {st }}$ difference & 20,72 & 3,44 & 2,86 & 2,56 & 0,00 \\
\hline
\end{tabular}


Sumber :Hasil Uji Statistik

Tabel

menunjukkanstasioneritas data harga ekspor CPO, harga minyak kedelai dunia, inflasi, pajak ekspor CPO dan produksi domestik CPO stasioner pada tingkat first difference. Sedangkan variabel kurs stasioner pada tingkat level.

\subsection{Uji Kointegrasi Engle Granger}

Uji kointegrasi Engle Granger dilakukan untuk memperoleh hubungan jangka panjang yang stabil antara variabel variabel yang terintegrasi pada derajat yang sama. Berdasarkan uji stasioneritas, seluruh variabel dalam penelitian ini stasioner pada derajat yang sama yaitu first difference.
Selanjutnya dapat dilakukan Uji Kointegrasi Engel Granger dengan meregresikan persamaan antara variabel dependen dengan variabel independen.Residual persamaan yang diperoleh diuji kembali danjika residual tidak memiliki unit akar dapat dikatakan bahwa variabel yang digunakan cenderung menuju keseimbangan jangka panjang.Berdasarkan hasil kointegrasi Engel Granger terbentuk persamaan untuk mengidentifikasikan hubungan ekspor CPO dengan harga ekspor CPO, harga minyak kedelai, produksi CPO, inflasi, kurs, dan pajak ekspor CPO.

\section{Tabel 3 . Uji ADF pada residual pesamaan regresi}

\begin{tabular}{|c|c|c|c|c|c|c|c|c|c|c|c|c|}
\hline \multirow{3}{*}{$\begin{array}{c}\text { Variabe } \\
1\end{array}$} & \multicolumn{4}{|c|}{ ADF Variabel } & \multicolumn{4}{|c|}{ ADF Persamaan Regresi } & \multirow{3}{*}{$\begin{array}{c}\mathrm{ADF}_{\text {Stat }} \\
\text { residua } \\
1 \\
\mathrm{ADF}_{\text {stat }}\end{array}$} & \multicolumn{3}{|c|}{$\begin{array}{c}\text { Test critical } \\
\text { values }\end{array}$} \\
\hline & \multicolumn{2}{|c|}{ Level $[\mathrm{I}(0)]$} & \multicolumn{2}{|c|}{$\begin{array}{c}\text { First } \\
\text { Different } \\
{[\mathrm{I}(1)]}\end{array}$} & \multicolumn{2}{|c|}{ Level $[\mathrm{I}(0)]$} & \multicolumn{2}{|c|}{$\begin{array}{c}\text { First } \\
\text { Different } \\
{[\mathrm{I}(1)]}\end{array}$} & & $1 \%$ & $5 \%$ & 10 \\
\hline & $\underset{\mathrm{t}}{\mathrm{ADF}_{\text {sta }}}$ & Prob & $\underset{\mathrm{t}}{\mathrm{ADF}_{\text {sta }}}$ & Prob & $\underset{t}{\mathrm{ADF}_{\text {sta }}}$ & $\begin{array}{c}\text { Pro } \\
b\end{array}$ & $\mathrm{ADF}_{\text {stat }}$ & $\begin{array}{c}\text { Pro } \\
\text { b }\end{array}$ & & & & \\
\hline $\mathrm{VEC}^{*}$ & 5,94 & $\begin{array}{c}0,0 \\
0\end{array}$ & $\begin{array}{c}20,7 \\
2\end{array}$ & $\begin{array}{c}0,0 \\
0\end{array}$ & & & & & & & & \\
\hline $\mathrm{HEC}$ & 1,70 & $\begin{array}{c}0,4 \\
2\end{array}$ & $\begin{array}{c}29,9 \\
8\end{array}$ & $\begin{array}{c}0,0 \\
0\end{array}$ & & & & & & & & \\
\hline HMK & 2,03 & $\begin{array}{c}0,2 \\
7\end{array}$ & $\begin{array}{c}20,2 \\
0\end{array}$ & $\begin{array}{c}0,0 \\
0\end{array}$ & 95,73 & $\begin{array}{c}0,0 \\
0\end{array}$ & $\begin{array}{c}1001,2 \\
6\end{array}$ & $\begin{array}{c}0,0 \\
0\end{array}$ & 7,62 & $\begin{array}{c}3,4 \\
4\end{array}$ & $\begin{array}{c}2,8 \\
6\end{array}$ & 2,56 \\
\hline PC & 2,78 & $\begin{array}{c}0,0 \\
6\end{array}$ & $\begin{array}{c}19,3 \\
4\end{array}$ & $\begin{array}{c}0,0 \\
0\end{array}$ & & & & & & & & \\
\hline I & 7,98 & $\begin{array}{c}0,0 \\
0\end{array}$ & $\begin{array}{c}17,9 \\
0\end{array}$ & $\begin{array}{c}0,0 \\
0\end{array}$ & & & & & & & & \\
\hline
\end{tabular}




\begin{tabular}{|c|c|c|c|c|c|c|c|c|c|c|c|c|}
\hline \multirow{3}{*}{$\begin{array}{c}\text { Variabe } \\
1\end{array}$} & \multicolumn{4}{|c|}{ ADF Variabel } & \multicolumn{4}{|c|}{ ADF Persamaan Regresi } & \multirow{5}{*}{$\begin{array}{c}\mathrm{ADF}_{\text {Stat }} \\
\text { residua } \\
1 \\
\mathrm{ADF}_{\text {stat }}\end{array}$} & \multicolumn{3}{|c|}{$\begin{array}{c}\text { Test critical } \\
\text { values }\end{array}$} \\
\hline & \multicolumn{2}{|c|}{ Level [I(0)] } & \multicolumn{2}{|c|}{$\begin{array}{c}\text { First } \\
\text { Different } \\
{[\mathrm{I}(1)]}\end{array}$} & \multicolumn{2}{|c|}{ Level $[\mathrm{I}(0)]$} & \multicolumn{2}{|c|}{$\begin{array}{c}\text { First } \\
\text { Different } \\
{[\mathrm{I}(1)]}\end{array}$} & & $1 \%$ & $5 \%$ & 10 \\
\hline & $\mathrm{ADF}_{\mathrm{t} \text { sta }}$ & Prob & $\mathrm{ADF}_{\text {sta }}$ & Prob & $\mathrm{ADF}_{\mathrm{t} \text { sta }}$ & $\begin{array}{c}\text { Pro } \\
b\end{array}$ & $\mathrm{ADF}_{\text {stat }}$ & $\begin{array}{c}\text { Pro } \\
b\end{array}$ & & & & \\
\hline K & 0,31 & $\begin{array}{c}0,9 \\
7\end{array}$ & $\begin{array}{c}18,4 \\
6\end{array}$ & $\begin{array}{c}0,0 \\
0\end{array}$ & & & & & & & & \\
\hline PE & 1,56 & $\begin{array}{c}0,4 \\
9\end{array}$ & $\begin{array}{c}30,3 \\
8 \\
\end{array}$ & $\begin{array}{c}0,0 \\
0 \\
\end{array}$ & & & & & & & & \\
\hline
\end{tabular}

$(*)$ adalah variabel dependen

Sumber :Hasil Uji Statistik

Setelah teruji kointegrasi antar variabel maka dapat dirumuskan persamaan kointegrasi jangka panjang ECM.Kointegrasi jangka panjang dirumuskan dengan memasukkan bentuk default dari persamaan regresi yang telah diperoleh, yaitu:

$$
\begin{aligned}
& (\widehat{V E C})_{t}=10,176,15+33,09(H E C)_{t}+ \\
& 0,69(H M K)_{t}-162,72 I_{t}-1,52 \mathrm{~K}_{t}- \\
& 99,07(P E)_{t}+0,15(\mathrm{PC})_{t} R^{2}=0,840939
\end{aligned}
$$

Estimasi diatas dapat dipercaya karena $84 \%$ atau 0,840936 variabel independen terkointegrasi terhadap ekspor CPO.Koefisien ekspor CPOcenderung mengalami peningkatan sebesar 33,09 satuan jika harga ekspor CPO meningkat sebesar 1 satuan. Koefisien harga minyak kedelai menunjukkan sebesar 0,69berarti bahwa ekspor CPO akan meningkat sebesar 0,69 satuan jika harga minyak kedelai meningkat sebesar 1 satuan. Koefisien inflasi adalah $\quad-162,72$,hal ini menggambarkan bahwa setiap peningkatan inflasi 1 satuan cenderung akan menurunkan ekspor CPO sebesar 162,72 ton. Namun nilai ini tidak signifikan dengan nilai probabilitas 0,87. Koefisien kurs menunjukkan nilai yang signifikan dengan koefisien-1,52 yang menggambarkan jika terjadi peningkatan kurs sebesar 1 satuan akan menunrunkan ekspor CPO sebesar 1,5 ton. Variabel pajak ekspor memiliki koefisien-99,07yang menggambarkan bahwa jika pajak ekspor dinaikkan pemerintah sebesar satu satuan cenderung akan menurunkan ekspor CPO Indonesia sebesar 99,07 ton. Variabel terakhir adalah produksi CPO (PC). Koefisien kointegrasi jangka panjang produksi CPO adalah 0,15. Nilai tersebut menunjukkan adanya peningkatan ekspor CPO sebesar 
0,15 satuan jika produksi $\mathrm{CPO}$ akan mempengaruhi secara tidak meningkat sebesar 1 satuan.

Selanjutnya Error Correction

Model (ECM) dilakukan dengan meregenerasi residual dan diperoleh persamaan sebagai berikut :

$$
\begin{array}{r}
V E C_{t}=69,47+4,79 H E C+16,76 H M K \\
-3615,37 I-4,84 K-16 \\
0,007 P C-0,77 \text { Res }_{t}
\end{array}
$$$$
-3615,37 I-4,84 K-16,14 P E+
$$

Hasil estimasi tersebut menunjukkan bahwa model ini dapat menjelaskan bahwa VEC terkait dengan HEC, HMK, I, K, PE, dan PC pada estimasi ECM sebesar 83\%.Estimasi VEC dengan variabel independennya menggambarkan keseimbangan jangka pendek. Selain itu juga diperoleh speed of adjustment sebesar 77\%. Hal ini menunjukkan bahwa variabel independennya akan menyesuaikan pada titik keseimbangan sebesar $77 \%$ dari titik keseimbangan awal dalam kurun waktu 1 minggu.

Harga ekspor CPO tidak terkait signifikan terhadap ekspor CPO. Hal ini ditunjukkan dengan nilai probabilitas dengan $\alpha 5 \%$ yaitu 0,74. Nilai koefisien 4,79 untuk harga ekspor CPO pada persamaan ECM menggambarkan bahwa peningkatan 1 satuan harga ekspor langsung ekspor CPO sebesar 4,79 satuan. Variabel harga minyak kedelai, kurs, pajak ekspor dan produksi domestik CPOtidak terkait terhadap ekspor CPO. Hal ini diakibatkan nilai probabilitas keempat variabel tersebut berada ditas nilai $\alpha$ 5\% yaitu 0,0517 untuk harga minyak kedelai, 0,0985 untuk kurs, 0,6377 untuk pajak ekspor, dan 0,6791 untuk produksi domestik CPO. Untuk melihat nilai keterkaitan empat variabel tersebut dapat dilihat dari nilai koefisiennya dimana 16,76 untuk harga minyak kedelai, $-4,84$ untuk kurs, -16,14 untuk pajak ekspor dan 0,007 untuk produksi domestik CPO. Nilai koefisien persamaan harga minyak kedelai menggambarkan bahwa pada estimasi ECM ekspor CPO akan meningkat sebesar 16,76 satuan jika harga minyak kedelai meningkat sebear 1 satuan. Nilai koefisien kurs yang menunjukkan nilai - 4,84 menunjukkan bahwa pada estimasi ECM ekspor CPO akan menurun sebesar 4,84 satuan jika kurs meningkat sebesar 1 satuan. Nilai koefisien pajak eksporadalah -16,14 yang berarti bahwa pada estimasi ECMekspor CPO akan menurun 
sebesar 16,14 satuan jika terjadi peningkatan pajak ekspor sebesar 1 satuan. Variabel terakhir yang tidak signifikan yaitu produksi $\mathrm{CPO}$ memiliki nilai koefisien sebesar 0,007 yang berarti bahwa pada estimasi ECM ekspor CPO akan meningkat sebesar 0,007 satuan jika terjadi peningkatan produksi $\mathrm{CPO}$ sebesar 1 satuan.

Nilai signifikansi variabel independen yang berada dibawah nilai $\alpha 5 \%(0,05)$ adalah variabel inflasi yaitu 0,0335. Hal ini menunjukkan bahwa variabel inflasi dalam jangka pendek secara langsung terkait pada ekspor CPO.nilai koefisiennya adalah 3615,370 menunjukkan bahwa ekspor CPO akan cenderung meningkat sebesar 3615,37 satuan jika inflasi meningkat sebesar 1 satuan. Pada penelitian terdahulu, variabel inflasi tidak dijadikan variabel independen atau regresor dalam kointegrasi jangka pendek.Maka dari itu tida ada perbandingan interpretasi variabel jangka pendek penelitian ini dengan penelitian terdahulu.

\section{KESIMPULAN DAN}

\section{SARAN}

\section{Kesimpulan}

1. Volume ekspor CPO dengan harga ekspor $\mathrm{CPO}$, harga minyak kedelai dan produksi CPO menunjukkan keterkaitan positif. Sedangkan antara volume ekspor CPO dengan inflasi, kurs, dan pajak ekspor menunjukkan keterkaitan.

2. Pada persamaan Error Correction Model (ECM) memperlihatkan keterkaitan positif antara volume ekspor CPO dengan harga ekspor CPO, harga minyak kedelai dan produksi CPO. Sedangkan antara volume ekspor $\mathrm{CPO}$ dengan inflasi, kurs, dan pajak ekspor menunjukkan keterkaitan negatif.

\section{Saran}

1. Kepada produsen dan eksportir CPO.

Produsen CPO harus tanggap melihat perkembangan harga ekspor CPO.Sedangkan untuk eksportir diharapkan tanggap pada perkembangan pajak ekspor dan harga minyak kedelai.

2. Kepada Pemerintah.

Pemerintah diharapkan mampu mengontrol pajak ekspor CPO. 
3. Kepada peneliti selanjutnya.

Peneliti selanjutnya diharapkan meneruskan penelitian ekspor CPO dengan mengganti metode analisis data dengan kointegrasi ARDL.

\section{DAFTAR PUSTAKA}

Brooks Chris. 2008. Introductory

Econometrics For Finance

Second Edition. Cambridge

University Press. New York.

Britania Raya.

Gerber James. 2014. International

Economics Sixth Edition. San

Diego State University.

Amerika Serikat

Kemenkeu. 2015. Kajian

Signifikansi Bea Keluar

Terhadap Hilirisasi Industri

Sawit. Badan Kebijakan Fiskal

Pusat Kebijakan Pendapatan

Negara Kementerian Keuangan

Republik Indonesia. Jakarta.

Maryana Embang. 2011. Analisis

Hubungan Kausalitas Ekspor

CPO Dengan Nilai Tukar Dan

Harga Minyak Bumi (Periode 2000-2010). Institut Pertanian

Bogor. Bogor
Muslih, et al. 2013.Faktor-faktor yang mempengaruhi ekspor $\mathrm{CPO}$ provinsi

Lampung.Program Studi Agribisnis Fakultas Pertanian Universitas Lampung.

Pratiwi Elysa. 2011. Analisis Determinan Ekspor Crude Palm Oil (CPO) Indonesia Ke Uni Eropa. Universitas Sumatera Utara. Medan.

PTPN V. 2015. Hilirisasi CPO: Kemenperin Dorong Petani Sawit Perbaharui Teknologi. http:// www.bumn.go.id/ptpn5/berita/0hilirisasi-cpo-kemenperin-dorongpetani-sawit-perbaharuiteknologi. Diakses Di Medan Pada Minggu, 26 Maret 2017

Putra Nuransyah. 2011. Analisis Determinan Volume Ekspor Minyak Kelapa Sawit Provinsi Sumatera Utara. Univeristas Sumatera Utara.

Radifan Fakhrus. 2014. Faktor Faktor yang Mempengaruhi Ekspor Crude Palm Oil Indonesia Dalam Perdagangan Internasional

Supriana Tavi. 2011. Ekonomi Makro. USU Press. Medan 
